\title{
From Rage to Rap and Prison to Print:
}

Social, Cultural and Commercial Contexts in the Emergence of Gang Memoirs

Josephine Metcalf

\section{(2) OpenEdition}

\section{Journals}

Electronic version

URL: https://journals.openedition.org/ejas/7651

DOI: 10.4000/ejas.7651

ISSN: 1991-9336

Publisher

European Association for American Studies

Electronic reference

Josephine Metcalf, "From Rage to Rap and Prison to Print:", European journal of American studies [Online], 4-2 | 2009, document 5, Online since 05 November 2009, connection on 08 July 2021. URL: http://journals.openedition.org/ejas/7651 ; DOI: https://doi.org/10.4000/ejas.7651

This text was automatically generated on 8 July 2021.

Creative Commons License 


\title{
From Rage to Rap and Prison to Print:
}

\author{
Social, Cultural and Commercial Contexts in the Emergence of Gang \\ Memoirs
}

Josephine Metcalf

\section{Introduction}

1 By the late 1980s, while thousands of former gang members were either dead or incarcerated, their legacy and the gang subculture was being celebrated and commodified through gangsta rap music and videos, film and fashion. In the early 1990s this lucrative cultural trend sparked interest from potential authors and publishers. Such literary attention was partially fuelled by a public fascination with life in the ghettos following the 1992 Los Angeles (LA) riots, resulting in a new trend of gang memoirs emerging in the US. Their content centered on contemporary street gang life in the ghettos and barrios, offering graphic tales of violent confrontation and territorial belonging. They were written by former gang members, both African American and Latino. The majority were set in LA, the city dubbed the gang capital of America.

Three of the most successful and influential of these gang memoirs form case studies in this article. Sanyika Shakur's Monster: The Autobiography of an LA Gang Member (1993) is an account of 'gangbanging' with one of the infamous African American "Crips" gangs in South Central LA during the 1980s. ${ }^{1}$ The memoir, written from prison, reveals how Shakur earned the nickname "Monster" for his brutal behavior before undergoing a political and personal transformation. Several months after the publication of Monster, Luis J. Rodriguez released Always Running: La Vida Loca - Gang Days in LA. ${ }^{2}$ Rodriguez reflects on his involvement with Mexican American gangs in East LA during the 1960s and 1970s. Like Monster, the narrative balances the tales of gang conflict with a politicized conversion narrative, informed by the Chicano Movement of the 1960s and 1970s.

3 Monster and Always Running acted as literary prototypes for this production trend in contemporary gang memoirs, setting thematic and narrative conventions and also 
demonstrating considerable commercial potential. In 2004, with numerous gang memoirs published following the success of Monster, Stanley "Tookie" Williams published Blue Rage, Black Redemption: A Memoir. ${ }^{3}$ Written by one of the co-founders of the Crips gang that was established in South Central LA in 1971, it offers a longer history of gang culture and conflict. Between 1993 and the publication of Blue Rage in 2004, LA street gangs had continued to thrive. ${ }^{4}$ Given a death penalty sentence in 1981 , Williams converted from notorious former gang member to outspoken peace activist in the early 1990s. In 1996 he authored a series of anti-gang children's books that resulted in several nominations for the Nobel Prize before his execution in 2005. ${ }^{5}$

4 This article aims to position these contemporary street gang memoirs within prevailing gangsta culture, exploring how LA gang experiences and cultural practices came to be narrativized and sold in popular form. This chronology will commence in the early twentieth century with the history of Mexican American gangs, progressing to the origins of the African American Crips in the 1970s, whose establishment is seen to denote the emergence of contemporary street gangs. Social, economic and political changes in inner-city areas at this time wreaked havoc for the urban youth of LA and sparked massive gang proliferation among Mexican and African Americans. Membership of these urban gangs continued to grow rapidly throughout the 1980s, prompting repressive police tactics, prison punishments, and extensive media coverage which in turn provided material for memoirs. I will consider the impact of existing gangsta trends on contemporary gang memoirs, highlighting the complex processes at work in the production of contemporary black and Latino popular culture. I will also explore other cultural expressions (such as 1960s prison narratives) and the inclinations of the publishing industry that encouraged the production of these texts.

2. LA Gang History

5 Monster, Always Running and Blue Rage narrativize the street gang phenomenon in LA from the late 1960s to the early 1990s, but to understand their frame of reference the longer history of gang activity and culture needs to be explained. Mexican American gangs in LA, such as the Maravillas and the White Fence, have a long and rich history. In California during the 1920s and 1930s, Mexican youth asserted their identities by forming gangs. Their working-poor families were lured to East LA by jobs and cheap housing. The Mexican experience of immigration posed huge problems with acculturation and assimilation and the barrios were segregated and overcrowded. Life for young people literally spilled out of the family home and onto the streets. Youths formed gangs as a protective, united front against racist, mainstream American society, but the gangs gradually turned on one another as neighborhood rivalries flared. Forced by schools and other institutions to sacrifice their culture, language and dignity, the self-descriptive identity label "Cholo" was deployed by youth to reflect their own street language and style. ${ }^{6}$ The glossary in Always Running defines this term as "A low life. [A term] appropriated by Chicano barrio youth to describe the style and people linked to local gang structures."7

6 These early barrio gangs were usually seen by the community as relatively harmless boys who wished to fight rival groups, rather than criminal gangs. ${ }^{8}$ The 1940 s have been seen as the point at which Mexican American gangs took a turn for the worse, becoming more dangerous in character and beginning to defy law enforcement. Paranoia about the "Zoot-Suiters" (so called because of Mexican fashion trends amongst young men) boiled over into riots in LA in 1942. Racial tension flared as 
Mexican American men became the target of white marines who were stationed in the city in preparation for the Second World War. The police initially refused to intervene and newspapers attacked the "pachucos", a term used to describe the Mexican youth of the 1930s and 40s with their own distinct style. Indeed, newspapers like the Los Angeles Examiner fuelled racial stereotyping by referring to the pachucos as "Mexican hoodlums". ${ }^{9}$ Indirectly attributable to the Zoot Suit Riots, the innocence of the barrio boys was lost and their competitive fighting at parties and on the streets evolved into more organized criminal gangs, partly out of self-protection. Heroin was introduced to the barrios in the post-war years (the drug was easily accessed by the cross-border movement of Mexican migrants) and the use of violence gradually increased throughout the next two decades.

7 Mexican American gangs therefore emerged in early twentieth century LA as an oppositional response to cultural marginality, but in the late 1960s and early 1970 s the African American Crips gang developed alongside the Black Panther party. The proliferation of modern-day gangs nationwide is often attributed to the founding of the Crips and their rival "Bloods" in South Central LA. Donald Bakeer wrote a historical novel about the rise of the Crips and offered one of the many versions of the gang's history. ${ }^{10}$ In this popular version, a teenager by the name of Raymond Washington admired the politically active Black Panthers who aimed to protect communities from what they deemed to be racist police officers. Together with his friend "Tookie" Williams, Washington established the Crips in order to unite his neighborhood and defend it against the police, emulating the Panther model of insurgent resistance. As one former gang member explains, "During the time period, everybody in the city was in a revolutionary mindset. You had the Black Panther party, the US Organization, all these organizations doing things. So the youngsters that wanted to be Black Panthers but couldn't, they created their own organizations, which became known as gangs."11 Joao Vargas's recent ethnography of African Americans in LA also uses evidence from former gang members to conclude that the Black Panthers and black power ideologies inspired street gangs in the 1970s. ${ }^{12}$

8 In a marginally different version of events from urban historian Mike Davis, the gang phenomenon known as "Crippin" became "the bastard offspring of the Panthers' former charisma." ${ }^{13}$ Rufus Schatzberg and Robert Kelly wrote a social history of African American organized crime which supports this version, maintaining that the Crips filled the void left behind when the Panthers were crushed by law enforcement. According to Schatzberg and Kelly, the Crips "inherited the Panther aura of fearlessness and transmitted the ideology of armed vanguardism ... they began as a teenage substitute for the fallen Panthers...evolving through the 1970s into a hybrid of teen cult and proto-mafia." ${ }^{14}$ In both historical versions, local violence soon expanded from skirmishes with the police to warring with rival neighborhood gang factions, particularly the Bloods. Despite such disagreements in contemporary gang history, most accounts stress the issues of the era: radical politics and responses to police harassment.

9 Social and economic changes in the 1970s gave rise to an increase in gang membership and a decrease in gang politicization. Regardless of the relationship the Crips may (or may not) have had with the Panthers, there is agreement that soon after the gang was established, as one anonymous social historian states, "the social fabric of LA began to unravel and disintegrate; solidarity lost out in a razor fight with survival." ${ }^{15}$ There is a 
clear correlation between the disintegration of the ghetto and the massive government disinvestment and privatization policies that affected inner city LA (areas such as South Central) throughout the 1970s. Employment in the barrios of East LA also took a turn for the worse, particularly with the area experiencing a tremendous increase in immigration from Mexico during the 1970s. Gang warfare became one symptom of the effect of mass de-industrialization in the 1970s as desperation set in, exacerbated by the loss of welfare due to cuts initiated by the Reagan administration in the 1980 s. These deteriorating urban circumstances for both Mexican and African Americans from the 1970s further stimulated gang growth in LA, in doing so supporting the social relevance of studying gangsta culture.

In the first year of the Reagan administration in 1981-82, cuts of $\$ 35$ million were made in budgets for education, housing, food stamps and school lunches. ${ }^{16}$ The situation for minorities was already grave before he came to power. According to the Department of Labor, in 1978 the unemployment gap between blacks and whites was the widest ever with the jobless rate among blacks being 2.3 times higher than the rate among whites. ${ }^{17}$ Indeed, in Monster, Shakur details his mother wearing "a fixed expression of hopelessness" even before the onset of 'Reaganomics'. ${ }^{18}$ Nonetheless, Reagan exacerbated the problem in failing to support affirmative action. Having won a popular victory at the polls without black or Mexican support, the President proceeded to propose legislation opposing the rights of minorities. His opposition to renewing the Voting Rights Act of 1965 was overruled by Congress, but he cut funds for civil rights enforcement agencies such as the Equal Employment Opportunity Commission. African Americans encountered similar racial impediments to gaining adequate housing. As sociologist James Blackwell claims with regard to Reagan, "His actions betray his public pronouncements decrying prejudice and abhorring discrimination." 19

11 In his inaugural address in 1989, President Bush promised to substitute Reagan's America with a "kinder, gentler" nation that would be more sensitive to the poor and the disadvantaged. ${ }^{20}$ During his first years in office, Bush and the Democraticcontrolled Congress raised the minimum wage and voted to provide financial support to low-income families for childcare. However the Bush administration was overshadowed by a prolonged economic recession that began in July 1990. By early 1992 over 2 million jobs had dried up, and the unemployment rate rose to 20 percent nationally. ${ }^{21}$ In December 1991 alone, General Motors, IBM and Xerox slashed 100,000 employees from their payrolls. ${ }^{22}$ Though the recession affected white collar as well as blue collar workers, it exaggerated an already dire employment situation for blacks and Mexicans. In 1992, 10 percent of whites were classified as "poor," but this figure was 26 percent for Latinos and 30 percent for African Americans. ${ }^{23}$ The situation was particularly bad in California, which had gained more people than any other state during the 1980 s, primarily due to Mexican immigration. ${ }^{24}$ The state simply could not provide sufficient jobs and adequate housing to keep its minority residents out of poverty and prevent the widespread growth of the ghettos, especially in urban areas like LA.

With insufficient employment and declining welfare benefits, criminality became a viable option, as demonstrated by the crack cocaine epidemic. This alternative drugs economy was first seen in LA in the early 1980s and, in providing income for Mexican and African American youth, it became a central part of street gang activity. As Shakur details, "Crack dealers employ more people in South Central than AT\&T, IBM, and 
Xerox combined." 25 Combined with increased access to firearms as a result of President Reagan's deregulation of guns, the drugs market resulted in a sudden upsurge in gang violence. Drive-by killings became a commonplace tactic of warring gangs, and the most common cause of death among young black and Mexican men was the bullet. ${ }^{26}$ Within a five year period in the mid-1980s, the homicide rate among young urban blacks quadrupled. ${ }^{27}$ Thus the 1980 s are often seen as the point at which the "supergang" was born. ${ }^{28}$ Despite the dangerous circumstances of street gangs, by the late 1980 s and early 1990s they had established themselves as extremely popular organizations amongst Mexican and African American young men.

The crack cocaine outbreak and subsequent rise in gang violence prompted stricter federal and state penalties for such crimes. Though Reagan had already declared a "War On Drugs," the vigorous response from police and officials towards gang violence led to the situation in LA also being described as "war." 29 Such a metaphor became commonplace in April 1988 when the LA Police Department (LAPD) and the LA County Sheriff's Department (LASD) under the command of Chief Darryl Gates launched Operation Hammer across ten square miles of LA. Thousands of black youths were forcibly seized and found their names being checked against computerized files of gang members. Gates justified the "invasion" by stating "This is war ... we're exceedingly angry ... we want to get the message out to the cowards out there that we are going to come and get them." ${ }^{30}$ In a media article which evaluated Operation Hammer, Mike Davis likened members of local black gangs to the "Vietcong," and gang members were also compared to the "murderous militias of Beirut" by some LA politicians. ${ }^{31}$ Such harassment, military-style offensives, and violent tactics from law enforcement towards street gangs would come to represent the tense relationship that existed between the two institutions, particularly throughout the late 1980s and early 1990 s.

As President, Reagan enacted the philosophy that it was simply not good politics to be soft on crime, an approach that was continued by Bush and Clinton. Reagan argued "Disarm the thugs and the criminals, lock them up and if you don't actually throw away the key, at least lose it for a long time..." ${ }^{32}$ During the Reagan presidency nine new prisons opened in California alone. ${ }^{33}$ Both Mexican and African American youth in contemporary LA endured the legacy of racist police chiefs and a discriminatory criminal justice system. Indeed, in Blue Rage Williams comments that "the emperor has no clothes in the prison system. His skin is white." ${ }^{34}$ In South Central and East LA during the early 1990s, incarceration affected numerous families. Even if one's own circle was not immediately involved, most knew neighbors, friends or distant relatives who were immersed in the legal system. By 1992 one quarter of all African American men nationally were in prison or jail, on probation, or on parole. ${ }^{35}$

As a result of Bush's stringent legislation and Clinton's "Three Strikes and You're Out," that figure has today increased to approximately one third of African American men aged 20-29. ${ }^{36}$ The incarceration rate for Latinos has also been significantly higher than for whites, though it has remained lower than for blacks. The chance that a Latino male will be in prison at least once in his lifetime is 16 percent; for African Americans that figure is 28 percent. ${ }^{37}$ (In Always Running, Rodriguez is aware he was lucky to escape a prison sentence. ${ }^{38}$ ) Such experiences of racist law enforcement and judiciary were reworked by gangs to discard negative connotations involving the "shame" of being a criminal, and embrace positive implications with prison sentences offering peer recognition and gang validation. 

street life. The traditional macho nature of the contemporary street gang has evolved into a ritual of storytelling with potential for bias and embellishment, as recognized by gang scholars. ${ }^{39}$ These hyperbolic warrior tales - what Williams terms "bullology" - are central to gangsta existence both on the streets and in prison. ${ }^{40}$ Eithne Quinn's cultural study of gangsta rap takes into account such high levels of gang violence, which provided exciting content for "powerful, realist tales about gangbanging conquests, murderous escapades, and tense poignant stories about loyalty and allegiance, sacrifice and loss." ${ }^{41}$ These war stories have since been converted into material for memoirs, both in terms of clashes with the LAPD and the LASD as well as internal gang strife.

\section{The Subcultural Practices of Gangs}

styles and rituals. Mexican American gangs historically paved the way for many subcultural trends of contemporary African American gangbangers such as low-riding and smoking "the chronic." In Always Running, Rodriguez acknowledges the influential impact of the Cholo's style and habits on contemporary gangs. ${ }^{42}$ Another popular ritual was reworking the prison Pendleton shirt as a trend for the streets, coined by sociologist Joan Moore as the "prisonization of street life." 43 Since then, subcultural inclinations within both groups have included hand-thrown set signals and graffiti marking territory. Gang members even manipulated fashion, using colored neck bandanas and sports caps to signify set affiliation. The gang's personalized vernacular was particularly notable for Cholos. ${ }^{44}$ These trends fit neatly with the scholarly studies of youth subcultures which thrived in the UK in the late-1960s.

The rise of subcultural studies in the UK is usually attributed to the Centre for Contemporary Cultural Studies (CCCS), founded in Birmingham in 1964. Stemming from the CCCS, Stuart Hall, Dick Hebdige, Ken Gelder and other cultural scholars explored the ways in which urban youth adapt and use emblematic rituals as symbolic responses to wider societal issues such as unemployment, poor wages or educational inequality. The Crips responded to living in this climate of urban decay by giving structuralist meanings to their own style politics and rituals, as their Mexican American counterparts had done. Like their Mexican forerunners, yearning for identity (to acquire social status) is a powerful incentive for joining an African American gang, as explored by gang sociologist Malcolm Klein ("the dean of gang researchers"). Gang monikers supplant birth names, creating exciting and playful new possibilities for individual identity, as part of identification with the larger gang unit. ${ }^{45}$

19 Cultural historian Robin Kelley explores Malcolm X's participation in the subculture (clothes, music and dance) of black working class youth during the Second World War as detailed in The Autobiography of Malcolm X. ${ }^{46}$ According to Kelley, partaking in this subculture helped Malcolm X and other young men to establish identities that resisted the hegemonic culture of the era with its ingrained racism and white nationalism. Kelley maintains that black youth constructed their own subcultural image as a direct response to prevalent social issues of the era. Similarly, the development of the gangsta subculture needs to be contextualized in the wider economic, political and social setting of America, California and specifically LA.

20 Gang subcultures take on further social significance because of their marketability. The actual gang experience, with its traditions and customs, is converted into cultural form and entertainment. Hebdige notes that youth subcultures are initially highly creative in 
their rebellion against mainstream culture. Despite being established as personally symbolic styles, such inventive trends frequently develop public market potential. ${ }^{47}$ The gangsta neck-scarf and Pendleton shirt became fashionable in the 1980s even outside the ghetto in a way that Hebdige deems "currency for exchange." ${ }^{48}$ Kelley recognizes this potential in contemporary subcultural models. He proposes that urban play is "more than an expression of stylistic innovation ... and/or racial and class anger - increasingly it is viewed as a way to survive an economic crisis or a means to upward mobility." 49 The gang's subcultural responses to societal hardship quickly became material for economically lucrative gangsta rap and its videos. As we will see, gang memoirists have similarly exploited subcultural appropriations as capital.

4. The Rise of Gangsta in Media and Popular Culture

21 Contemporary street gangs became a popular sensational topic in the press from the late 1980s onwards. A broad area of enquiry in gang studies has been the gang's problematic relationship with the printed media and news programs. The media soon became the public's principal resource for information about gangs, exploiting a public fascination with the subject. The dramatic portrayal of gangs in the media spread misinformation and created moral panics. In Always Running, Rodriguez voices concern that the media's reporting style was deliberately intended to "create a hysteria against black and Latino youth." ${ }^{50}$ Gang scholars Klein and Martin Jankowski raise awareness of the powerful and influential role of all media in affecting public opinion on gangs. They criticize the media's tendency to lean towards sensationalized news coverage of gangs in order to stimulate audience interest. Jankowski deems this the media's "exploitation of the concept of violence," a notion which also underpins discussions of the violent imagery and commercial impetus of gang memoirs. ${ }^{51}$

In addition to the printed media and news, street gangs could soon also be seen in various entertainment outlets. The use of the subject of gangs in recreational forms was partially sparked by the immense popularity of urban gangs for marginalized youth. Klein labeled this process "the cultural diffusion of gangs." 52 Information about gangs could be garnered from various popular sources rather than just the press.

Prior to the arrival of contemporary street gang memoirs in the 1990s, rap proved how such secretive gangsta subcultures, inaccessible to the majority of the public, could provide captivating true-to-life material for popular texts. This intrigue was partially fuelled by a longstanding white fascination with black masculinity which Norman Mailer branded "coolness envy" in the 1950s. ${ }^{53}$ Contemporary historian Kevin Starr attempts to understand the culture of modern-day California by quoting a white, upper-class seventeen year-old who observed the trends at his high school: "Everyone is totally into inner-city street language ... there is a lot of yearning to be black." ${ }^{4}$ The likes of Eminem and Vanilla Ice have embraced and interpreted contemporary black rap styles, though white fascination with blackness has been traced as far back as the minstrel shows that gained popularity in the mid-nineteenth century. Longings for blackness certainly spurred the commercial success of rap, and its popularity was further fuelled by its candid first-person form. Quinn argues that such music satisfied the "vast appetite for 'black ghetto realness' in the popular culture marketplace," by "mobiliz[ing] the authenticity discourse." 55 Such "street-realist reportage" could offer white, suburban audiences an immediate insight into black ghetto culture, feeding their curiosity. ${ }^{56}$ The music's unruly and anti-establishment themes further attracted white audiences. 

often credited with paving the way for gangsta rap. This music involved rapped lyrics over backing beats, often accompanied by break-dancing and graffiti, and was popular among African American and Latino youth cultures. By the mid-1980s, a distinctive version of rap was becoming popular on the West coast, becoming increasingly preoccupied with violent tales from the inner-city. The term "gangsta rap" was invented by artist Ice Cube in 1989 and his original band, Niggaz With Attitude (NWA), became the first gangsta rap act to reach number one on the Billboard pop album chart in June 1991. The success of their album, Niggazulife, points to a moment when gangsta rap became truly mainstream, and by late 1991 gangsta rap had generated an impressive $\$ 700$ million in music sales. ${ }^{57}$ Cultural studies scholar Todd Boyd stresses the influential role of rap in this era, arguing that "in essence to talk about gangsta culture is to talk about gangsta rap. The music provides the themes and ethos of this particular cultural movement." ${ }^{58}$ Shakur demonstrates a keen awareness of this musical genre in his acknowledgements in Monster. He includes dedications to early rap groups Public Enemy and Boogie Down Productions (who had reputations for being politically conscious), as well as renowned gangsta artists Ice-T, Ice Cube and Tupac Shakur. ${ }^{59}$ Such dedications position gangsta rap as a significant and immediate precursor to and inspiration for gang memoirs.

years after Ice-T and NWA's first singles and just as Operation Hammer was being launched, in April 1988 the film Colors was released. Though "white" in being directed by Dennis Hopper, the film sparked the ghetto action movie cycle of the early $1990 \mathrm{~s} .{ }^{60}$ Hollywood responded quickly to the commercial success of gangsta rap, channeling ghetto authenticity through another medium for popular consumption. The old white ethnic "gangster" and the black gangster of blaxploitation films were displaced by a new villain. ${ }^{61}$ As one advertising tagline actually read, "They're a new breed of gangster." 62 This African American "gangsta" would prove to be extremely lucrative despite the films being low-budget productions. ${ }^{63}$ The success of Colors with its graphic depiction of gang life prompted further blockbusters with mostly African American directors. These included: John Singleton's Boyz N The Hood, Mario Van Peebles's New Jack City and Matty Rich's Straight Out of Brooklyn (1991), Edward Olmos's American Me, Ernest Dickerson's Juice, Stephen Anderson's South Central (1992), Allen/Albert Hughes' Menace $l l$ Society and Allison Anders's Mi Vida Loca (1993). ${ }^{64}$

South Central was the film version of Donald Bakeer's prominent book, Crips: The Story of the LA Street Gang from 1971-1985. ${ }^{65}$ Published in 1987 as a novel, Crips depicted historical characters including Raymond Washington. In 1992 the book was converted by Anderson into the provocative film (produced by Oliver Stone) which came out on limited release for fear of inflaming public violence following the LA riots earlier that year. Nonetheless, 50,000 video copies were sold during its first week, demonstrating the market for gangsta in film as well as musical forms. ${ }^{66}$ The movie industry's swift response to the success of gangsta rap was certainly worthwhile. Such films would be critically acclaimed by film critics and journalists as original and factual portraits of gang life, representing ethnic poverty and societal injustices and creating a theatrical reality that captured the public imagination. ${ }^{67}$

Cultural scholars have contended that gangsta rap and ghetto action films formed part of a black cultural movement that originated with those who have suffered most by the conditions of post-industrial America and years of deliberate race and class 
subordination. ${ }^{68}$ Whilst specific sociological subcultures - such as the contemporary street gang - have thrived in response to oppressive and restrictive mainstream society, Boyd identifies this distinctive "ghetto" black popular culture as a similar response. One of the most prominent theorists on contemporary black culture, Cornel West, notes the irony that "just as young black men are murdered, maimed and imprisoned in record numbers, their styles have become disproportionately influential in shaping popular culture." ${ }^{69}$ There is some irony that black and Mexican youths were struggling through life and yet thriving in popular culture. The growth of this popular trend - "gangsta" - in reaction to, and as a reflection of political and economic climates, reinforces the social relevance of studying the meaning of contemporary gang memoirs within this wider insatiable appetite for gangsta culture.

Contemporary street gangs were also a new and exciting subject for documentary films. In his book review of Monster for Atlantic magazine in December 1993, journalist Mark Horowitz noted "it is now much in fashion to go to gang members in LA for the authentic voice of black experience - or at least the experience of the black underclass." 70 Horowitz argued that prior to Monster this phenomenon had been evident on television, citing Ted Koppel's interviews on news channel ABC in the wake of the 1992 LA riots. In the weeks following the uprising the public watched in fascination as gang members who had been arch enemies called a truce. Commentator Koppel interviewed Lil' Monster (Shakur's brother) as well as rival gang members. On national television these young men criticized society's treatment of the lower-classes and raised awareness of living conditions in the poverty-stricken ghettos of South Central and East LA. Yet even prior to Koppel's discussions, in 1989 three television documentaries on gangs had appeared: Dan Medina's Our Children: The Next Generation, Dan Rather's 48 Hours: On Gang Street, and Tyne Daly's Not My Kid. ${ }^{71}$ Each of these programs incorporated interviews with real life gang members, were widely promoted, and were watched nationwide by large audiences.

By the late 1980s, although the gangsta subject was firmly established in several media and popular forms, printed word accounts of gangs remained limited. Boyd argues that the lonesome black gangster figures in the earlier literature of Donald Goines and Iceberg Slim were the precursors setting the stage for gangsta culture to prosper in the 1980s. ${ }^{72}$ Authors such as Goines, Slim and Walter Dean Myers had previously demonstrated the popularity of fiction addressing life in America's ghettos (written and set in the 1970s and 1980s), as this genre was well-liked amongst juvenile readers and was available in high school libraries across California. ${ }^{73}$ One high school librarian I interviewed referred to these texts as "African American popular fiction" while her colleague deemed them "ghetto/urban fiction." ${ }^{44}$ Both agreed such texts were "full of sex, drugs, violence, very racy and extremely popular." Yet such authors did not specifically engage with contemporary street gangs as their primary subject.

There was another extremely important literary precursor to the emergence of gang memoirs. In the three-year period up to 1992 when the movie Malcolm X was being made, sales of The Autobiography of Malcolm X increased 300 percent. ${ }^{75}$ Gangsta rappers were already covering the story of the politicized black power hero whose memoir was originally published in 1965. African American interest in Malcolm X and his message was revived during the conservative Reagan presidency. Rapper Ice Cube, for example, frequently referred to Malcolm X, while Tupac often referenced the black power era. ${ }^{76}$ Boosted by the publicity surrounding Spike Lee's film, The Autobiography of Malcolm X 
was the bestselling paperback book during the Christmas 1992 sales period. The memoir also renewed an awareness of and fascination with the prison narrative genre that included works by Eldridge Cleaver and George Jackson and which had been so popular in the late 1960s and early 1970s.

31 Such earlier prison narratives were a significant influence on Shakur, Williams and Rodriguez. Shakur admits in Monster to being "stunned" when he learnt of the parallels between himself and George Jackson, whose prison letters, Soledad Brother, were published in $1970 .{ }^{77}$ In Blue Rage, Williams pays homage to Malcolm X who "underwent a miraculous change from seemingly permanent criminal to reborn black man" as illustrated in The Autobiography of Malcolm X (1965). ${ }^{78}$ Williams and Shakur draw comparison with earlier prison writers due to their incarcerated status and like Rodriguez, they are authors originating from the bottom of society with no education. Rodriguez did not publish from prison but similarly takes inspiration from prison authors or those who have experienced prison. Piri Thomas' Down These Mean Streets (1967) was cited as a primary influence in Always Running. ${ }^{79}$ Such referencing sparks comparisons between the two groups of authors, in which earlier prison memoirs can be seen as literary precursors to contemporary street gang memoirs.

The Autobiography of Malcolm X was not the only success story amongst minorities in the literary scene of the early 1990s. The year leading up to the release of Monster and Always Running produced bestsellers from other African American authors including Toni Morrison, Alice Walker and Terry McMillan. ${ }^{80}$ Alongside this was the fact that, according to Book Industry Trends 1993, booksellers were recognizing the growing Latino population of the US and increasing their numbers of Spanish books. ${ }^{81}$ Despite the general recession of the late 1980s and early 1990s, the publishing industry thrived with 200 book superstores opening in $1992 .{ }^{82}$ The industry's optimism was further fuelled by the election of President Clinton in 1993. Clinton, an avid book fan, was expected to encourage the expansion of the book market and increase library revenues. The trend for diverse multicultural projects continued through early 1993 with the popularity of Maya Angelou, Morrison receiving the Nobel Prize in Literature, and the founding of the American Writers of Color Literary Agency.

33 Additional trends in the publishing world at this time paved the way for Monster and Always Running to be released in 1993. In April 1993, an article in Publisher's Weekly noted how "true crime" books saturated the literary market in the early 1980s and explored why the genre continued to be extremely popular. ${ }^{83}$ True crime stories are generally assumed to be biographical rather than autobiographical, for example second-hand accounts of infamous serial killers, but the nature of the genre offers insight as to why gang memoirs are alluring. Publisher's Weekly claimed "publishers and booksellers agree that psychological insight into the minds of killers, some rational explanation for monstrous behavior, and the fallout of such crimes on the community in which they occur are the strongest components of the genre." 84 Gang memoirs satisfy similar voyeuristic impulses with protagonists justifying their passionate and aggressive behavior and discussing the impact of gangs on the ghetto. Violent gang memoirs thus fulfilled the public's demand for sensationalized crime.

When Clinton was elected, America was in shock over the beating of Rodney King in March 1991 and the LA riots in April 1992 that resulted from the acquittal of the accused police officers. Both Mexican and African American gang memoirists took advantage of these riots. Alonso, who is also an independent publisher (releasing the 
second installment of memoirs by former gang member Terrell Wright), claimed that such texts are often quietly signed or released to little acclaim..$^{85}$ According to Alonso they often become well-known later, following adverse events. He cited the example of the riots aiding the popularity of Monster and the execution of Williams encouraging sales of Blue Rage. According to Quinn, general paradoxes can be viewed with regards to gangsta rap: "The ironies run deep: these artists turned the very social costs of urban poverty, violence, and social isolation into assets;" the idea that "horrible living conditions, and above all LA's brand of urban crisis, actually lent themselves to dramatization and exploitation." 86 Both Monster and Always Running address the riots in their prefaces and epilogues, using the 1992 violence to frame their life stories.

5. The Emergence of Gang Memoirs

Rodriguez was the first of the three memoirists to secure a publishing contract, although Shakur's memoir would be released first in 1993. Rodriguez wrote throughout the 1980s, finally being signed by Curbstone in July 1991. In the early 1980s, Rodriguez decided to novelize his life story, only to receive rejections from 22 publishing houses. ${ }^{87}$ The text only gained attention amongst publishers when he re-wrote the book as a memoir rather than fiction. In one of many rejection letters that Rodriguez received from publishers in the mid 1980s, Bantam House informed him that they had released their current "quota" of Latino books and would not be undertaking any more for ten years ${ }^{88}$ When Rodriguez finally secured a book deal, Curbstone was a small, non-profit press that dealt with social subjects, human rights and cultural issues. ${ }^{89}$ It was familiar with the author, having already published some of his poetry.

Gangsta rap, ghetto films, and the media coverage of gangs were dominated in the late 1980 s and early 1990s by African American artists and producers, despite the successes of a few Mexican Americans such as rapper Kid Frost and the group Aztlan Underground. There were also a few other Latino rap artists who were commercial triumphs, including Mellow Man Ace and Cypress Hill. Frost's hits suggested there was some appetite for Mexican American barrio tales and thus a potential market for Mexican American artists. Edward James Olmos's film American Me (1992) was the first blockbuster to highlight the Chicano gang life. American Me takes its name from Beatrice Griffiths's 1948 text, which offers insights into early twentieth century Mexican American history and depicts how the gang lifestyle in LA was already entrenched at that time. ${ }^{90}$ Despite this long-standing history of Mexican American gangs, popular culture trends of the late 1980s and early 1990s advocated a clear favoritism for African American tales of the "hood. To some degree this rationalizes the attitude of Bantam House and others, who initially failed to see the lucrative potential of Always Running.

37 Although the stereotype of a Californian gang member is often an African American, recent studies have verified that LA's Latino gangs in the late 1980s and early 1990s were even greater in number than their African American counterparts. ${ }^{91}$ Notwithstanding the huge numbers of Latino gangbangers, the racial profiling of Operation Hammer demonstrates the way the public imagination has remained fixated on the black gangbanger. In an interview, Rodriguez spoke adamantly about "the urgent need for my book" from a Latino viewpoint. ${ }^{92}$ Rodriguez was concerned that such coverage and literature ignored the plight of Latinos in gangs as well as ghetto life more generally. He claims "this story had to be told" because "it's the first major account of the Chicano gang experience from an actual participant." 93 Mexican 
Americans similarly experienced life in LA as marginalized residents throughout the 1980 s, so it was surprising that in discussions of the 1992 riots Latinos should be omitted, particularly when they were the largest minority group among the 18,000 arrested. ${ }^{94}$ At the time of the riots, the media coverage framed events as black/white, interviewing solely African Americans as authentic authorities on the occurrences in the inner-city, and rendering Latinos voiceless. The media coverage of these riots later came under extensive criticism for under-representing the Latino contribution, including Cholo involvement in the gang truce.

An article in Publisher's Weekly in December 1992 entitled "In aftermath of LA riots, a lively diversity of voices" claims Curbstone went "all out" for Always Running with a 7,000 copy hardcover printing and a national book tour that was unprecedented for such a small press. ${ }^{95}$ Weekly acknowledges that it is difficult to ascertain solutions to racial tensions in the post-riot period, but believes that "if understanding diversity is key to relieving ethnic and social tension, book publishing is doing its part to reflect a wide spectrum of opinion on just what happened in LA." ${ }^{96}$ Such optimism is counterbalanced by Susan Faludi, writing for the alternative LA Weekly, who believes that this publishing industry was simply selfishly "eager for a piece of the marketable LA riots drama." ${ }^{17}$ Whether for conscientious or profitable reasons, publishers proved their sensitivity to social and minority issues and a readiness to exploit real life drama. In an interview with Rodriguez, the memoirist joked that his friend accused him of starting the rebellion as a means of publicizing Always Running. Rodriguez disclosed that his contract had in fact been signed prior to the uprising in April 1992, but acknowledged that Always Running was released at a particularly appropriate point in social history. As he explained, "the LA riots opened the door to my book - they came at just the right time." 98

As Rodriguez was in the midst of negotiating his Curbstone contract in 1991, journalist Leon Bing released a book on the Crips and the Bloods. ${ }^{99}$ Bing's short biographical accounts of street gang life, which usually included first-hand interviews with gang members, began to appear in newspapers and journals nationwide in the late 1980s. She played a crucial role in paving the way for Monster and paving the way for written gang memoirs. Her book, Do Or Die, became an instant bestseller in 1991 even though she was writing about a subject "before it was fashionable [in literature]." 100 The subtitle for Do Or Die was compelling: "For the first time, members of America's most notorious teenage gangs - the Crips and the Bloods - speak for themselves." A chapter was dedicated to Shakur, interviewed by Bing whilst incarcerated, and his brother Lil' Monster. Shakur featured alone on the cover photograph. He pays homage to Bing in Monster's acknowledgements for "writing about us when it was unpopular to do so," referring to the negative coverage that gangs were receiving in the press at that time. 101

Bing subsequently introduced the still-imprisoned Shakur to William Broyles, a journalist who was seeking gang members from South Central for a television pilot. The program was never commissioned but Broyles saw the literary potential in Shakur, encouraging him to start writing his memoirs. Broyles was responsible for initial drafts being published in Esquire magazine in April 1993 and instigating publishing interest in the whole text. While Broyles believed he had the only draft of Monster, Shakur quietly sent his manuscript elsewhere and a bidding war ensued before Atlantic Press emerged the victor. Atlantic had merged the previous year with Grove Press, which had an 
established reputation for publishing the work of radical political thinkers (they released a collection of Malcolm X's speeches in 1969). When Shakur finally signed the formal contract in November 1992, Atlantic Press was deemed "a hip, independent publishing house." 102 Shakur explains "I just felt they [Atlantic] would allow me to express my point of view." 103 The substantial deal which Shakur himself negotiated with Atlantic (a $\$ 150,000$ advance with the promise of additional payments of at least $\$ 100,000)$ was over double the amount Bing received for Do Or Die. ${ }^{104}$

41 At the Frankfurt Book Fair in late 1992, publisher Morgan Entrekin of Atlantic Press announced that he had purchased the rights for a memoir by an incarcerated LA gang member. This generated considerable interest amongst the audience, and curiosity in Monster was said to have eclipsed Madonna's infamous book Sex, as well as the latest offerings from bestselling authors John Clancy and Stephen King. ${ }^{105}$ Within two days, seven publishers in varying countries had purchased the foreign rights to Shakur's memoirs, praising themselves for spotting a "culturally important work." ${ }^{106}$ Like Horowitz, one of the original literary agents to view Monster defended this commotion, insisting that "we see so much of the violence of the American inner city; now here's a voice that comes from inside that can explain it to us." 107 Such justification echoed the demand for personalized gang tales rather than merely a book on gangs - as prompted by Bing - and also makes explicit the connection between media interest in gangs and the marketability of gang memoirs.

The memoir genre is encouraged by publishers who are working within a successful US tradition of profitable autobiography. From Benjamin Franklin to modern-day sports stars, memoirs have regularly topped non-fiction bestselling lists. Genre can certainly function as a commercial device, for instance being used as a labeling method in bookstores. ${ }^{108}$ Publishers interested in street gang tales are aware that life writing can be lucrative. It was only after Rodriguez re-worked the text as an autobiographical account that he secured a publisher. Similarly, when Shakur informed his publisher, Morgan Entrekin, that he wanted to focus his book on the history and development of contemporary gangs, Entrekin specified that Shakur should persevere with an autobiographical approach. In an interview with Shakur he classified his book as "social anthropology/sociology." ${ }^{09}$ But Entrekin protested "I'm not interested in gangs. I'm interested in you." 110 Shakur wanted to use the title Can't Stop, Won't Stop, but Entrekin fought for the usage of Monster: The Autobiography of an LA Gang Member, highlighting the power relations at play between author and publisher. Though Shakur could exercise independence in his initial search for a lucrative book deal, once signed it was the publisher who would set the terms for the memoir's title and focus. Entrekin's use of "autobiography" in the title demonstrated a keen awareness that the success of such a text depends on its engagement with the autobiographical genre, reflecting the popularity of gangsta rap because of its (supposedly) true-to-life anecdotes in firstperson form.

43 Like Curbstone, Atlantic used the gloomy social setting of 1992 to its benefit. Though Shakur had sent a chapter of his work to Broyles in 1991, it was following the 1992 riots that he secured a publishing contract and interest in his memoirs suddenly escalated. Entrekin was so assured of Shakur's prowess as a ghetto spokesperson and the sure success of his memoir in this atmosphere, that he originally announced he would publish Monster on the first anniversary of the 1992 LA riots (April 1993). ${ }^{111}$ The release date was later pushed back by a few months. 
Unlike Monster, the memoirs of Stanley "Tookie" Williams did not create an initial publishing furor. Like Rodriguez, Williams struggled to secure a publisher. The infamous former gangbanger began reading and writing on death row in the early 1990s, encouraged by his friend Barbara Cottman Becnel. Becnel contacted Williams in 1993 when she was researching a book about the history of the Crips. She soon became a regular visitor and abandoned her initial research plans to help Williams fulfill his desire to promote gang peace. Together they published their first texts in 1996, a series of anti-gang books aimed at elementary school children learning to read. ${ }^{112}$ The following year Williams released his first independent book Life in Prison, which targeted young adults, deploying shock tactics to scare them away from prison. ${ }^{113}$

In 1998 Becnel encouraged Williams to start writing his life history, and six years later his adult memoirs appeared, the delay partly a result of his struggle to find a willing publishing house. Many publishers were reluctant to associate with Williams because of his controversial death row status (he had experienced similar problems with his earlier texts). Eventually Williams suggested that Becnel establish Damamli Ltd. in 2004 for the sole purpose of releasing Blue Rage. He chose the Swahili word "Damamli" meaning "beautiful vision" as a title for the publishing house, and its mission statement reflected a distinct outlook on William's death row status: "All books and other media from this company will be dedicated to and defined by the notion that redemption is possible - that adults and kids can ... create real personal and spiritual growth."114 Damamli only issued the memoir in a paperback format, aware that the California prison system banned inmates from receiving hardback books.

46 Once Blue Rage had been released and shown a certain degree of popularity amongst its variety of readers, it was commercially logical for a larger publisher to step in and reap further benefits. Having sold 10,000 copies of Blue Rage, Damamli struggled to cope with the huge surge in demand for the memoir following Williams's execution in 2005. Having been asked by Williams to ensure that his memoir receive wide distribution, as executor of his estate Becnel sold the posthumous rights to Simon \& Schuster in 2007. Becnel believed the larger publishing house had a similar agenda to Damamli for publishing Blue Rage, claiming the two companies both "saw Stan's autobiography as a modern classic that would be read by students and adults for many, many years."115

In 1994 Touchstone, an offshoot of Simon \& Schuster, issued the first of many more paperback editions of Always Running. According to Rodriguez "eight big publishers initially bid for the paperback rights ... the rebellion and all this attention meant [they] could do a paperback." 116 Rodriguez received an initial payment of $\$ 60,000$, a sum significantly larger than he had received in 1991 from Curbstone. ${ }^{117}$ In 1994 an article in the Washington Post addressed the contemporary climate of the publishing industry and its treatment of African Americans, raising accusations of exploitation. The article criticized publishers for being most interested in texts such as Monster and former gang member Nathan McCall's Makes Me Wanna Holler, and expressed disappointment that publishers correlate black writers with tales of criminality. ${ }^{118}$ Such concerns over representational responsibility did not discourage Penguin Books from re-releasing Monster in 1994. Penguin marketed the book along similar lines to Atlantic, keeping the same image of Shakur on the cover that had initially been taken for the cover of Do Or Die.

48 Since Monster was published in 1993, the publishing industry and the reading public have continued to seek out books that describe the ghettos and barrios and their 
gangbanging residents from first-person perspectives. Other bestselling gang memoirs in addition to Monster, Always Running, Blue Rage and Makes Me Wanna Holler include those by Geoffrey Canada (1996), Mona Ruiz (1997), Snoop Dogg and Bill Lee (1999), Reymundo Sanchez (2000 and 2003), Colton Simpson and Terrell Wright (2005) and DaShaun "Jiwe" Morris (2008). ${ }^{119}$

Literary scholar David Brumble has begun to define the genre of gang memoirs, citing 27 such authors who should be classified together, including the contemporary street gang memoirists mentioned in this chapter. ${ }^{120}$ Brumble's bibliography incorporates prison narratives from the 1960s and 1970s, which suggests that 1993 may be seen as a point of re-emergence for gang memoirs. From this perspective, it could be argued that the street gang memoirs that appeared from 1993 onwards sprung from the juncture between the historical popularity of the prison memoir and the new demand for gangsta cultural stories. The latter was proven by gangsta rap and ghetto films and intensified at a particular historical moment thanks to the Rodney King riots.

Regardless of whether this cycle of memoirs commencing in 1993 can be deemed original or re-emerging, Monster, Always Running and Blue Rage can be seen as explicitly representative of the genre. These three memoirs reveal a great deal about social relations, especially pertaining to race, gender, class and generational issues in an urban context at a particular historical moment. The narratives provide a window into the urban environment of LA where contemporary street gangs grew rapidly, particularly from the 1970s onwards. These memoirs, like the genre more generally, offer "inside" accounts of the social problems associated with gangs and the costs to urban communities of high levels of violence. At the same time the memoirs open up profound insights into and critiques of the social-structural determinants of gangs. They draw out revealing connections between the proliferation of street gangs and both de-industrialisation and the erosion of welfare support since the 1970s. Thus these narratives, as representations of everyday gang practices, include important social commentary. These three particular memoirs as case studies, for example, all engage with issues of youth unemployment, substandard education, rising poverty levels and racial conflict, while each one focuses on a separate moment in the post-1965 period of crisis and transition.

6. Conclusions

51 The continuing demand for gangsta stories in pop culture is evident. Rodriguez and Wright are contracted to release the second installment of their memoirs, while Sanchez is about to publish his third. A docudrama about Monster has been filmed (entitled Can't Stop, Won't Stop) and is due for release in late 2009, while Shakur is in negotiations for a major motion picture deal. Shakur currently resides in solitary confinement at Pelican Bay State Prison from where he released a novel entitled T.H.U.G. L.I.F.E. in August 2008. ${ }^{121}$ Blue Rage was made into a high-profile television movie in 2004 (starring Hollywood celebrity Jamie Foxx) and Rodriguez has also sold the film rights to Always Running. A 2009 documentary, Crips and Bloods: Made in America, explores the growth of contemporary street gangs through the eyes of former gang members, demonstrating an ongoing fascination with the subject. ${ }^{122}$ Though gangsta rap is often seen to have reached its zenith in the mid-1990s, artists like The Game and 50 Cent are still signing multi-million dollar record deals, while Eminem recently topped the Billboard chart with an album slickly produced by Dr Dre. ${ }^{123}$ 
Just like the earlier deployment of gangsta in popular music and film, the autobiographical narratives that first appeared in 1993 provided compelling insight into life as a resident in the ghettos and barrios of LA. Life in the so-called "City of Angels" was not easy for Mexican residents in the peak periods of immigration early in the twentieth century, or Mexican and African Americans towards the end of the century. The predicament of minorities in LA at this time served as evidence of the urban malaise that would blight barrios and ghettos across the country, spawning gangs and later gangsta culture. There is some irony that this city, with its difficult socio-economic circumstances, is simultaneously so well-known for the vast entertainment system that was significantly responsible for producing and promoting gangsta culture.

As well as detailing gang styling and the reasons for gang membership, the memoirs include exciting anecdotes of warring with other gangs and gripping tales of altercations with the police. Like gangsta rappers before them, the narrators of these memoirs voiced resentment at the criminal justice system and their marginalization in contemporary American society. These artists, both musicians and authors, turned their negative experiences into positive resources. Despite popular culture's initial preference for African American gangsta tales, publishing houses and other entertainment industries have happily incorporated both Mexican and African American slants on the gang lifestyle. Their experiences were converted into cultural form as part of a larger popular penchant for gangsta that could also be witnessed in films and the news.

Josephine Metcalf, University of Manchester

\section{NOTES}

1. Sanyika Shakur, Monster: The Autobiography of an LA Gang Member (New York: Penguin, 1993). The original hardback edition of Monster was released in 1993 by Atlantic.

2. Luis J. Rodriguez, Always Running - La Vida Loca: Gang Days in LA (New York: Touchstone, 1994), 4. The original hardback edition of Always Running was released in 1993 by Curbstone.

3. Stanley "Tookie" Williams, Blue Rage, Black Redemption: A Memoir (Pleasant Hill, CA: Damamli, 2004).

4. From 1993 to 2003, in LA alone over 10,000 youths died in gangrelated deaths. See Claudia Durst Young, Youth Gangs in Literature (Westport, CT: Greenwood, 2004), xvi.

5. Williams with Barbara Cottman Becnel, Tookie Speaks Out Against Gang Violence series (New York: Rosen, 1996).

6. For Mexican American gang history see James Diego Vigil, Barrio Gangs: Street Life and Identity in Southern California (Austin: University of Texas, 1988) and his essay "Community Dynamics and the Rise of Street Gangs," in Marcelo Suarez-Orozco and Mariela Paez (eds.), 
Latinos: Remaking America (Berkeley: University of California, 2002), 97-109.

7. Rodriguez, Always Running, 254.

8. Durst Young, Youth Gangs, 176.

9. Author unknown, "Hair Style Used in Identification of Hoodlums;

Suspects Must Not Change Haircut, Judge Rules", Los Angeles Examiner, 27 October 1942. See PBS website for more information on the press and the riots: http://www.pbs.org/wgbh/amex/zoot/eng_sfeature/sf_press.html. See also Raúl Damacio Tovares, Manufacturing the gang: Mexican American Youth Gangs on Local Television News (Westport, CT: Greenwood Press, 2002), 51.

10. Donald Bakeer, Crips: The Story of the LA Street Gang from 1972-1985 (Los Angeles: Precocious, 1987), 28.

11. Yusuf Jah and Sister Shah'Keyah, Uprising: Crips and Bloods Tell the Story of America's Youth in the Crossfire (New York: Touchstone, 1997), 329. In a different twist on this story, Klein argues that some members of the small, localized gangs that were already established at the time (such as the Gladiators and the Slausons) actually left their gangs to join the Black Panthers and Ron Karenga's US organization. Interview with Malcolm Klein conducted by the author, December 2006.

12. Joao Costa Vargas, Catching Hell in the City of Angels: Life and Meanings of Blackness in South Central LA (Minneapolis: University of Minnesota, 2006), 180.

13. Mike Davis, City of Quartz (London: Verso, 1990), 298.

14. Rufus Schatzberg and Robert Kelly, African Americans Organized Crime: A Social History (New Brunswick: Rutgers University, 1997), 197. 15. The new afterword to James Carr's Bad: The Autobiography of James Carr (London: Pelagian, 1995), 209. Bad was originally released in 1975. It says the afterword was "Completed June 1993" but the only clue to authorship is the addresses for "News From Everywhere" and "BM Blob." Presumably it was a collaborative exercise from Pelagian Press.

16. George Tindall and David Shi, America: A Narrative History (New York: Norton, 1993), 954.

17. Alphonso Pinkney, The Myth of Black Progress (Cambridge:

Cambridge University, 1984), 74.

18. Shakur, Monster, 252.

19. James Blackwell, The Black Community; Diversity and Unity (New York: Harper \& Row, 1985), 76.

20. George H.W. Bush, "Inaugural Address," 20 January 1989. See the full text at http://www.nationalcenter.org/BushInaugural.html

21. Tindall and Shi, America, 992.

22. Ibid.

23. Ibid, 976.

24. Ibid, 998.

25. Shakur, Monster, 70.

26. Tindall and Shi, America, 976.

27. Stephen Levitt \& Stephen Dubner, Freakonomics (London: Penguin, 2006), 103. 
28. Durst Young, Youth Gangs, xxiii.

29. This included, for example, the Reagan Administration's Anti-Drug Act in 1986, which was further expanded in 1988. Mike Davis, "War in the Streets," New Statesman, 11 November 1988, 28.

30. Ibid.

31. Ibid.

32. The American Civil Rights Union, "Reagan on Gun Control and SelfDefense," available at http://www.theacru.org/blog/2007/04/

reagan_on_gun_control_and_selfdefense/.

33. Angela Davis, Are Prisons Obsolete? (New York: Seven Stories, 2003), 12-13.

34. Williams, Blue Rage, 319.

35. Tindall and Shi, America, 976.

36. Vargas, Catching Hell, 14.

37. Lee Stacy (ed.), Mexico and the US (New York: Marshall Cavendish, 2003), 667.

38. Rodriguez, Always Running, 233.

39. Klein, The American Street Gang: Its Nature, Prevalence and Control (Oxford: Oxford University, 1995), 78.

40. Williams, Blue Rage, 250.

41. Eithne Quinn, Nuthin' But A "G" Thang: The Culture and Commerce of Gangsta Rap (New York: Columbia University, 2005), 54.

42. Rodriguez, Always Running, 5.

43. Joan Moore, "Bearing the Burden: How Incarceration Policies Weaken Inner-City Communities," in Vera Institute of Justice, The Unintended Consequences of Incarceration, conference papers, 1996, 73-75.

44. What Vigil calls "Spanglish". See Vigil, "Community Dynamics" in Suarez-Orozco \& Paez (eds.), Latinos, 103.

45. Klein, American Street Gang, 27, 45, 60, 200.

46. Robin Kelley, Race Rebels: Culture, Politics and the Black Working Class (New York: Free Press, 1994), 163.

47. Dick Hebdige, Subcultures: The Meaning of Style (London: Routledge, 1979), 131; Ken Gelder and Sarah Thornton (eds.), The Subcultures Reader (London: Routledge, 1997), 85.

48. Hebdige as quoted in Quinn's Nuthin' But A “G" Thang, 53.

49. Kelley, Yo' Mama's Dysfunktional! Fighting the Culture Wars in Urban America (Boston: Beacon, 1998), 45.

50. Rodriguez, Always Running, 6.

51. Martin Jankowski, Islands in the Street: Gangs and American Urban Society (Berkeley: University of California, 1992), 229.

52. Klein, American Street Gang, 205.

53. Norman Mailer as quoted in Quinn, Nuthin But A "G" Thang, 85.

54. Kevin Starr, Coast of Dreams: A History of Contemporary California (London: Allen Lane, 2005), 87. See also Stacey Patton, "The Rap on Whites who Try to Act Black," The Washington Post, 16 March 2008. 55. Quinn, Nuthin' But a "G" Thang, 32. 
56. Ibid, 10. Quinn explains that by the early 1990s, audience statistics showing a 65 percent white market share for hardcore rap. See Quinn, Nuthin' But a "G" Thang, 82-83.

57. NWA, Niggaz4life (Ruthless/Priority, 1991). Quinn, Nuthin' But a "G" Thang, 8.

58. Todd Boyd, Am I Black Enough for You? Popular Culture from the 'hood and Beyond (Bloomington: Indiana University, 1997), 91.

59. Shakur, Monster, vii.

60. Colors (Dennis Hopper, 1988).

61. Boyd, Am I Black Enough for You?, 88.

62. New Jack City (Mario Van Peebles, 1991). See Jonathan Munby, "From Gangsta to Gangster: The Hood Film's Criminal Allegiance with Hollywood," in James Chapman, Mark Glancy and Sue Harper (eds.), The New Film History (New York: Palgrave, 2007), 166-179 (169).

63. Munby, "From Gangsta to Gangster", 171.

64. Note that Olmos is Mexican American and Anders is white, while the rest are African American. Boyd argues that the three films most relevant to understanding gangsta culture are Boyz $N$ The Hood, Menace II Society and American Me, see Boyd's Am I Black Enough for You?, 92.

65. Bakeer, Crips.

66. See http://donaldbakeer.com/book_sc.html.

67. S. Craig Watkins, Representing: Hip Hop Culture and the Production of Black Cinema (Chicago: University of Chicago, 1998).

68. Boyd, Am I Black Enough for You?, 10-11.

69. Cornel West as quoted in Andrew Milner and Jeff Browitt, Contemporary Cultural Theory $3^{\text {rd }}$ edn. (London: Routledge, 2002), 157. 70. Mark Horowitz, "In Search of Monster," Atlantic (December 1993),

28-37.

71. Jankowski, Islands, 290.

72. Boyd, Am I Black Enough for You?, 91.

73. In December 2006 and January 2008 I visited several LA high school libraries, and nearly all held books by Goines and Myers.

74. Author interview with a high school librarian in California, December 2006.

75. David Ansen and Spike Lee, "The Battle For Malcolm X," Newsweek, 26 August 1991.

76. For example, Ice Cube's "When Will They Shoot?" and "Wicked," both of which appear on his album The Predator (Priority/EMI, 1992). See also Quinn, Nuthin' But a "G" Thang, 175.

77. Shakur, Monster, 219. George Jackson, Soledad Brother: The Prison Letters of George Jackson (London: Jonathan Cape, 1970).

78. Williams, Blue Rage, 283.

79. Rodriguez, Always Running, 50. Piri Thomas, Down These Mean Streets (New York: Vintage, 1997, [1967]).

80. See http://www.publishingtrends.com/ for further information. Also Book Industry Trends 1993: Covering the Years 1987-1997 (New York: Book Industry Study Group Inc., 1993), prepared by the Statistical Service Center. 
81. Book Industry Trends 1993, 14.

82. Ibid.

83. Tom Weyr, "Marketing America's Psychos," Publisher's Weekly, 12 April 1993, 38.

84. Ibid.

85. Author interview with Alonso, December 2006.

86. Quinn, Nuthin' But a "G" Thang, 42, 65.

87. Author interview with Rodriguez, January 2008.

88. Ibid.

89. Margo Nash, "Once Upon A Time," New York Times, 18 September 2005.

90. Beatrice Griffith, American Me (Boston: Houghton Mifflin, 1948), 32.

91. For instance, gang statistics published by the LAPD in December 1993 suggest the presence of 35,865 Latino gang members compared to 21,944 African Americans.

For further details see: http://www.lapdonline.org/assets/crime_statistics/gang_stats/ 1993_97_gang_stats/93_12_sum.htm.

92. Author interview with Rodriguez, January 2008.

93. Ibid.

94. Rodriguez, Always Running, 247.

95. Michael Coffey and Lisa Kendall, "In aftermath of LA riots, a lively diversity of voices," Publisher's Weekly 239 (28 December 1992), 24. 96. Ibid.

97. Susan Faludi, "Ghetto Star," Los Angeles Weekly, 6 October 1999.

98. Author interview with Rodriguez, December 2006.

99. Leon Bing, Do Or Die: For the First Time, Members of America's Most Notorious Gangs - The Crips and The Bloods - Speak For Themselves (New York: Harper Collins, 1991).

100. Shakur, Monster, viii.

101. Ibid.

102. Amy Wallace, "The Monster Deal," Sunday Age (Melbourne), 25 April 1993.

103. Written author interview with Shakur, November 2008.

104. Faludi, Stiffed: The Betrayal of the American Man (London: Chatto \& Windus, 1999), 482.

105. Horowitz, "In Search of Monster", 28-37; Robert Lusetich, "Monster With Attitude," Weekend Australian, 1 June 1996.

106. Wallace, "The Monster Deal."

107. Horowitz, "In Search of Monster", 28-37.

108. Jerry Palmer, Potboilers; Methods, Concepts and Case Studies in Popular Fiction (London: Routledge, 1991), 115.

109. Written author interview with Shakur, November 2008.

110. Faludi, Stiffed, 482.

111. Horowitz, "In Search of Monster", 28-37.

112. Williams with Becnel, Tookie Speaks Out series (New York: Rosen, 1996). Aided by Becnel, in 1997 Williams established "Tookie's corner," an internet education program as part of the Institute for the Prevention of Youth Violence. See www.tookie.com/ 
113. Williams, Life in Prison (New York: Morrow Books, 1998).

114. All profits from Blue Rage were ploughed by Damamli into LA-based community projects with dedicated help from Becnel. See

www.damamli.com/ and www.tookie.com/

115. Ibid.

116. Author interview with Rodriguez, December 2006.

117. Ibid.

118. Mary Ann French, "For black authors, the same old story? A roundtable look at literary roadblocks facing African Americans," Washington

Post, 13 June 1994, C1. Nathan McCall, Makes Me Wanna Holler: A Young Black Man in America (New York: Random House, 1994).

119. Geoffrey Canada, Fist Stick Gun Knife (Boston: Beacon, 1996); Mona Ruiz with Geoff Boucher, Two Badges: The Lives of Mona Ruiz (Houston: Arte Publico, 1997); Snoop Dogg with Davin Seay, Tha Doggfather: The Times, Trials and Hardcore Truths of Snoop Dogg (New York: William Morrow, 1999); Bill Lee, Chinese Playground: A Memoir (San Francisco: Rhapsody, 1999); Reymundo Sanchez, My Bloody Life: The Making of a Latin King and Once a King, Always a King: The Unmaking of a Latin King (Chicago: Chicago Review, 2000 \& 2003); Colton Simpson with Ann Pearlman, Inside The Crips: Life Inside LA's Most Notorious Gang (New York: St. Martin's, 2005); Terrell Wright, Home of the Body Bags (Venice, CA: Senegal, 2005); DaShaun "Jiwe" Morris, War of the Bloods in my Veins: A Street Soldier's March Toward Redemption (NY: Scribner, 2008). 120. Brumble kindly emailed me a copy of his bibliography for what he terms "Tribal Warrior Autobiographies."

121. Shakur, T.H.U.G. L.I.F.E. (New York: Grove/Atlantic, 2008).

122. Crips and Bloods: Made in America (Stacy Peralta, 2009).

123. Eminem, Relapse (Aftermath, Interscope \& Shady: 2009).

\section{AUTHOR}

JOSEPHINE METCALF

Josephine Metcalf, University of Manchester 